Research Article

\title{
Width Design of Small Coal Pillar of Gob-Side Entry Driving in Soft Rock Working Face and Its Application of Zaoquan Coal Mine
}

\author{
Ai Chen $\left(^{1,2}\right.$ \\ ${ }^{1}$ School of Energy and Mining Engineering, Shandong University of Science and Technology, Qingdao 266590, China \\ ${ }^{2}$ Ningxia Coal Industry Co., Ltd., of China Energy Group, Yinchuan 750000, China \\ Correspondence should be addressed to Ai Chen; aichennm@163.com
}

Received 12 April 2021; Revised 25 May 2021; Accepted 21 June 2021; Published 3 July 2021

Academic Editor: Jia Lin

Copyright (c) 2021 Ai Chen. This is an open access article distributed under the Creative Commons Attribution License, which permits unrestricted use, distribution, and reproduction in any medium, provided the original work is properly cited.

Reasonable width of gob-side coal pillar can reduce the waste of coal resources and is conducive to roadway stability. According to the distribution of internal and external stress fields at the working face, a method for determining the width of gob-side coal pillar was proposed. The coal pillar and roadway should be set within the internal stress field, and support is provided through the anchored part and the intact part of the coal pillar. The method was used in the design of the coal pillar at No. 130205 working face of Zaoquan Coal Mine. The calculation results indicated that the width of a coal pillar suitable for gob-side entry is $6.0 \mathrm{~m}$. It is reasonable to arrange the roadway and coal pillar in the low-stress zone with a width of $11 \mathrm{~m}$. During tunnelling of roadway and stoping of the working face, the deformation of the roadway increased with a reduction in the distance from the working face. Even during stoping of the working face, there was an approximately $1.5 \mathrm{~m}$ intact zone in the coal pillar. This indicates that the proposed method of designing small coal pillar of gob-side entry driving is reliable.

\section{Introduction}

With the continuous improvement of coal mining methods and the enhancement of the mechanical equipment level, fully mechanised caving has become an important mining method for thick coal seam [1-3]. It can achieve high-yield and high-efficiency mining of thick coal seams, but roadways in mining area face challenges of surrounding rock control, for example, the large cross section, strong mining influence, and soft and thick coal roof and floor [4-7]. Over the past few years, China has called for the construction of resource-saving mines [8]. Fully mechanised caving mining projects involving large-cross section roadway driving along goafs under narrow coal pillar conditions have become increasingly common, and the difficulty in controlling the stability of the surrounding rocks in these projects has increased.

A key issue in the fully mechanised caving of small coal pillars is the design of a reasonable width. A reasonable coal pillar width can not only reduce the deformation of the coal pillar and the maintenance costs, but also maximise the recovery of coal resources [9-11]. A century ago in the United States, the design of coal pillar dimensions depended heavily on intuition or established rules of thumb [12]. However, currently, various coal pillar design guidelines have been developed on the basis of indoor tests and theoretical analyses [13-16]. Sheorey et al. [13] analysed 23 cases of pillar instability and 20 cases of safe and stable pillars and proposed a new pillar strength equation for practical values of the width-to-height ratio. Aiming at the defect of traditional coal pillar safety evaluation method which regards safety factor as fixed value, Najafi et al. [14] proposed a coal pillar stability evaluation method which regards safety factor as probability function. He et al. [15] studied the correlation between the gob-side entry (GSE) stability and coal pillar width during longwall top-coal caving mining in extra-thick coal seams and found that the GSE with an $8 \mathrm{~m}$ coal pillar was destressed and minimal GSE deformation occurs. Fan et al. [16] calculated the range of the internal stress field from the perspective of the stress distribution in the surrounding rock, thereby determining the width of coal pillars and validating them onsite. 
In addition, with the advancement of field measurement and numerical simulation techniques, they have been increasingly applied to coal pillar design [17-24]. Focusing on the potential variation in strength due to the strength properties of the surrounding rock, Gale [17] proposed a design method for coal pillar arrangement. Jaiswal and Shrivastva [18] proposed a method for establishing the strain-softening constitutive relation of coal via calibration of a numerical model, and they determined the most appropriate strain-softening parameters and hence identified a reasonable coal pillar width. Esterhuizen et al. [19] calibrated the numerical model of coal pillar strength using FLAC3D according to triaxial test data of coal samples together with the failure depth and peak resistance of the coal pillar. Wu et al. [20] studied the initiation, propagation, and failure of cracks within a $7 \mathrm{~m}$ gob-side coal pillar during its formation and suggest that the most appropriate pillar width is $10 \mathrm{~m}$ in the Sijiazhuang Coal Mine in China.

In the foregoing studies, the width of the coal pillar was designed to maintain stability only under specific stress conditions. However, the design of the coal pillar is related to not only its own bearing capacity but also the stress environment in which it is located. When the coal pillar is designed to be in a high-stress area, its bearing capacity must be high, that is, a large width. Conversely, a coal pillar in a low-stress area must have a low bearing capacity and small width [25]. This study focused on soft rock roadway driving along the goaf of Zaoquan Coal Mine. A design method for the width of the coal pillar along the goaf was developed by combining the position of the chain pillar (stress conditions) and the bearing capacity of the coal pillar. The method was applied to Zaoquan Coal Mine.

\section{Study Area}

2.1. Geological Overview. Zaoquan Coal Mine is located at the edge of the Mu Us Desert, southeast of Lingwu City in Ningxia in northwestern China. The mine field is $13 \mathrm{~km}$ long from north to south and approximately $4 \mathrm{~km}$ wide from east to west, with an area of $52 \mathrm{~km}^{2}$. The bedrock strata in the mine field include the Upper Triassic Shangtian Formation, Middle Jurassic Yan'an Formation (coal-bearing strata), and Zhiluo Formation, as well as the Upper Jurassic Anding Formation, with the bedrock extensively covered by Quaternary wind-deposited sand or Palaeogene purplish-red clay. There are three main workable coal seams: No. 2, No. 6, and No. 8, which have thicknesses of $8.4 \mathrm{~m}, 2.6 \mathrm{~m}$, and $5.5 \mathrm{~m}$, respectively. The coal seam currently being mined is No. 2 .

2.2. Overview of Working Face. The coal seam mined at working face 130205-coal seam No. 2-is buried at a depth of approximately $615 \mathrm{~m}$. Its thickness ranges from 8.2 to $10.7 \mathrm{~m}$, with an average of $8.4 \mathrm{~m}$. It contains a layer of gangue (black carbonaceous mudstone) with an average thickness of $0.3 \mathrm{~m}$, which is $0.7 \mathrm{~m}$ from the immediate floor of the coal seam. The lithology of the pseudoroof of No. 2 coal seam is carbonaceous mudstone (average thickness of $0.4 \mathrm{~m}$ ), while that of the immediate roof is siltstone (average thickness of
$4.6 \mathrm{~m}$ ) and fine sandstone (average thickness of $3.2 \mathrm{~m}$ ), with the part above it being medium sandstone (average thickness of $12.7 \mathrm{~m}$ ) and fine sandstone (average thickness of $5.0 \mathrm{~m}$ ). The coal seam floor is siltstone (average thickness of $11.8 \mathrm{~m}$ ).

Airway 130205 opens at the return airway moving downhill of mining area No. 13, and the machine tunnel opens at the downhill belt conveyor of working face 130203 (where mining is completed) is above working face 130205. Coal safety pillars (35 m high) were set up in airway 130205 and machine tunnel 130203. The working face is bounded by normal fault F201 to the north and the shaft pillar in mining area No. 13 to the south. The part below working face 130205 is a primitive coal seam that has not been extracted; thus, there is no mining activity affecting the excavation of the working face.

The airway of working face 130205 has a length of $2,198 \mathrm{~m}$, with a cross section of length $\times$ width $=5,000 \mathrm{~mm}$ $\times 4,000 \mathrm{~mm}$. The machine tunnel has a length of $1,976 \mathrm{~m}$, with a cross section of length $\times$ width $=5,200 \mathrm{~mm} \times$ $4,000 \mathrm{~mm}$. The working face has a strike length of $1,910 \mathrm{~m}$ (with a workable length of $1,583 \mathrm{~m}$ ) and an inclination length of $332 \mathrm{~m}$ (cutting hole). The mining method of retreating longwall along the strike, the fully mechanised top-coal caving technique, and the full-caving method were adopted at the working face for the treatment of the goaf. The mining layout plan of working face 130205 is shown in Figure 1.

\section{Methodology}

3.1. Coal Pillar Design Method Based on Internal and External Stress Fields. During roadway excavation and maintenance, the sources of mine pressure and their corresponding excavation locations and timings under different chain pillar mining conditions were divided into three types, as shown in Figure 2 [25-27].

The first type was the excavation of a small coal pillar within the internal stress field and advancement due to mining of the relative working face before the formation and stabilisation of the internal stress field (Position 1 in Figure 2). The second type was advancement due to delayed mining of the working face after the stabilisation of the internal stress field (Position 2 in Figure 2). The third type was a roadway protection scheme using a large coal pillar, in which excavation was conducted in the high-stress area (Position 3 in Figure 2), with a low recovery rate owing to the large coal pillar and a large stress concentration factor.

For improving the coal recovery rate and reducing the stress concentration factor of coal pillar, the narrower the coal pillar is, the better. But considering the supporting effect of the coal pillar on the roof and the deformation degree of the surrounding rock of the roadway, the designed width of the coal pillar has a minimum value. If it is less than this value, the coal pillar will be easily broken, and the roadway will produce large deformation.

The width of the small coal pillar in the section was based on the comprehensive analysis of the effects of the stress, displacement, and width of the small coal pillar on the deformation of the roadway when the coal pillar was affected 


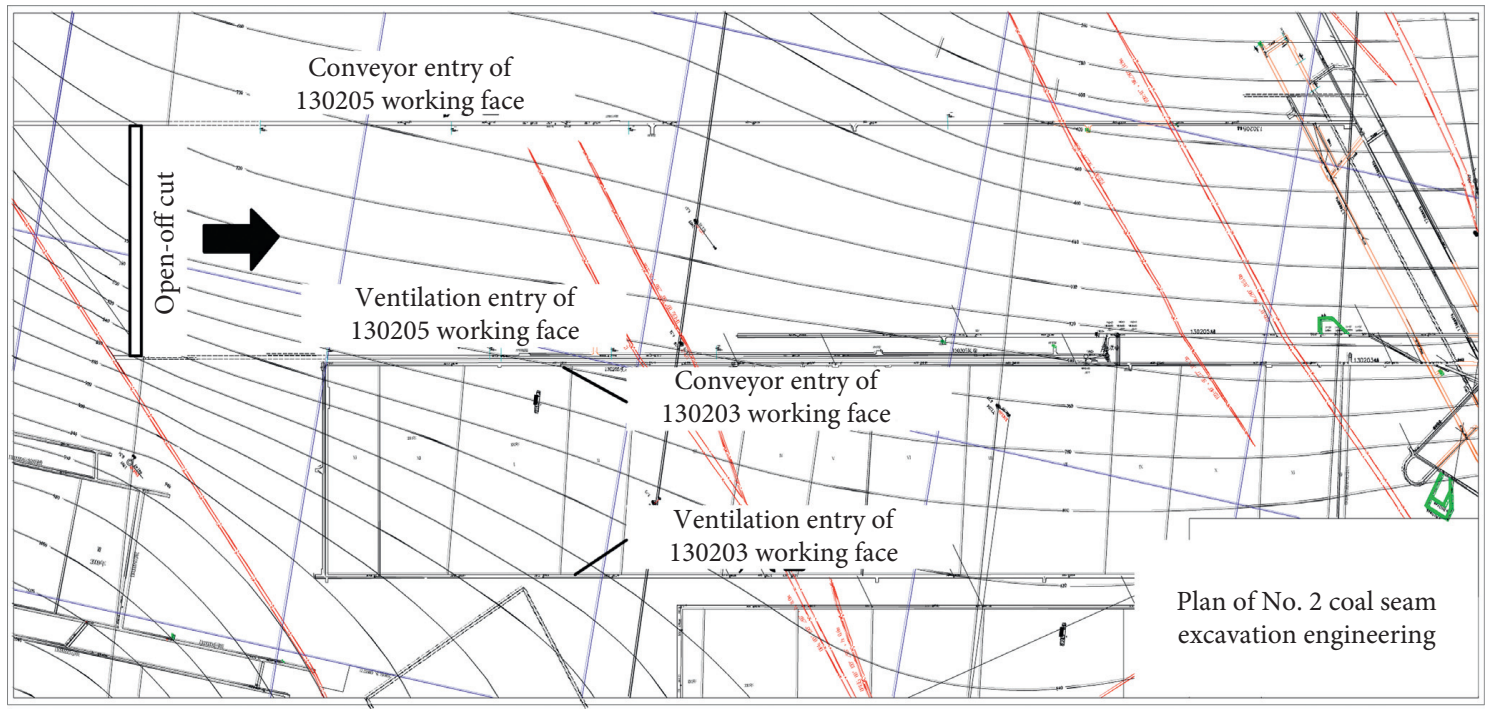

FIGURE 1: Relationship between the movement of the surrounding rock of the roadway and the abutment pressure distribution.

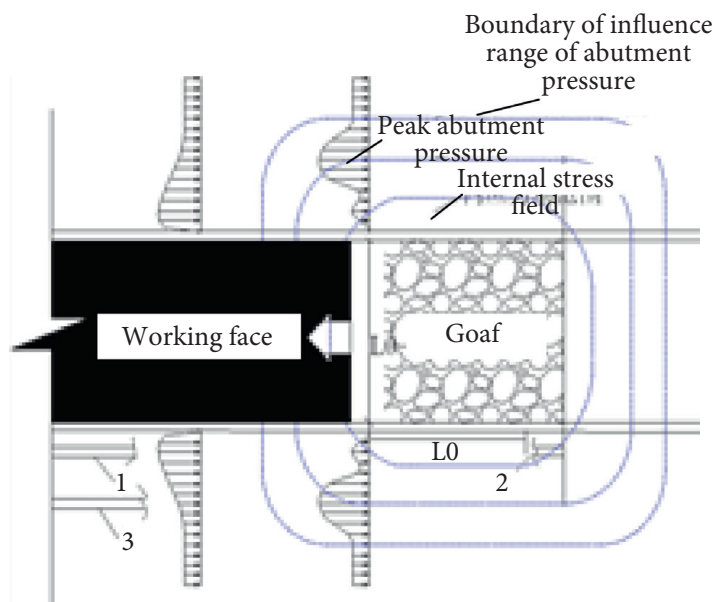

(a)

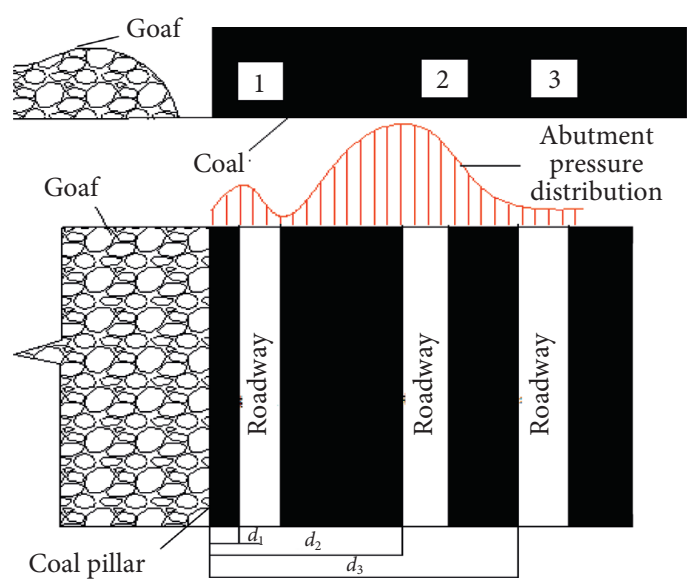

(b)

FIgURE 2: Relationship between the movement of the surrounding rock of the roadway and the abutment pressure distribution. (a) Plan and (b) profile.

by stoping of the working face in this section. The main factors affecting the working condition of the coal pillar included the following:

(1) Loading time: if the service time of the roadway was relatively long, a strength factor of prolonged service (with a value of 0.7 to 0.8 ) was used to correct the compressive strength of the specimen.

(2) Width-to-height ratio: the relationship between the coal pillar strength and width-to-height ratio $\left(S_{p}\right)$ can be expressed by the following equation [28]:

$$
S_{p}=\left(\frac{B}{h}\right)^{(1 / 2)} S_{c}
$$

where $S_{c}$ represents the strength at $B / h=1$ (i.e., the cubic strength) and $S_{p}$ represents the coal pillar strength at a width-to-height ratio of $B / h$.
(3) Load size: the degree of filling of the immediate roof in the goaf is directly related to the load size of the coal pillar. If the degree of filling was low, dynamic loading was significant. If the filling thickness was 3 to 5 times larger than the mining height, dynamic loading was not significant.

(4) Anchor reinforcement: after the roadway was excavated, stress failure occurred within the surface layer of the coal seam on both sides of the coal pillar, forming a failure zone in the internal stress field. Moreover, the coal pillar was reinforced with an anchor bolt, which significantly increased the lateral pressure of the coal pillar under certain conditions.

3.2. Calculation Method for Coal Pillar Width. The stability of roadway driving along the goaf must be maintained with the installation of a small coal pillar in this section of the 
roadway. The width of the coal pillar should be greater than the sum of the widths of the crushing zone on the side of the goaf and the anchorage zone. That is, it must be ensured that an intact zone is retained in the middle of the coal pillar to provide support, as shown in Figure 3. Hence, the reasonable minimum width $B$ of small coal pillars in the section of roadway driving along the goaf is calculated as follows:

$$
B=S_{1}+S_{2}+S_{3} \text {, }
$$

where $S_{1}$ represents the crushing zone created in the small coal pillar in the roadway driving along goaf in this section, whose width is given as follows [29]:

$$
S_{1}=\frac{m A}{2 \operatorname{tg} \phi_{0}} \ln \left[\frac{k \gamma H+\left(C_{0} / \operatorname{tg} \phi_{0}\right)}{\left(C_{0} / \operatorname{tg} \phi_{0}\right)+\left(P_{x} / A\right)}\right] \text {, }
$$

where $m$ represents the height of the roadway (in $\mathrm{m}$ ), $A$ is the coefficient of lateral pressure, $k$ is the stress concentration factor caused by excavation of the roadway, $\gamma$ represents the average unit weight of the overlying strata (in $\mathrm{kN} / \mathrm{m}^{3}$ ), $H$ represents the mining depth (in $\mathrm{m}$ ), $P_{x}$ represents the strength provided by the roadway support to the coal wall (in $\mathrm{MPa})$, and $C_{0}$ and $\varphi_{0}$ represent the cohesive force $(\mathrm{MPa})$ and the angle of internal friction $\left({ }^{\circ}\right)$ of the interface of the laminae of the coal mass, respectively.

$S_{2}$ represents the effective length of the anchor bolt in the sidewall of the roadway (in $\mathrm{m}$ ), with an additional reinforcement factor of $15 \%$.

$S_{3}$ represents the width of the elastic core zone in the middle of the coal pillar (in m). Assuming that the crushing zone of the coal pillar does not provide load bearing and that only the anchorage zone and the elastic core zone provide support, the width of the elastic core zone can be determined using the width-to-height ratio of this part of the coal pillar (equation (1)).

\section{Results and Discussion}

4.1. Calculation of Width of Coal Pillar at Working Face 130205. According to the equation for calculating the width of the coal pillar and the geological parameters of working face 130205, the width of the crushing zone of the small coal pillar $S_{1}$ was calculated as $1.8 \mathrm{~m}$, where $m=4 \mathrm{~m}, A=1.6$, $k=2.5, \quad \gamma=2512 \mathrm{kN} / \mathrm{m}^{3}, \quad H=615 \mathrm{~m}, \quad P_{x}=0.1 \mathrm{MPa}$, $C_{0}=1.5 \mathrm{MPa}$, and $\varphi_{0}=27^{\circ}$. The effective length of the anchor bolt in the sidewall of roadway was $S_{2}=2.3 \times(1+15 \%)=$ $2.6 \mathrm{~m}$. According to the uniaxial compressive strength $(24.6 \mathrm{MPa})$ and the coal mass strength of the plastic anchorage zone (22.3 MPa) of coal seam No. 2 of Zaoquan Coal Mine, it was found that the elastic core zone $S_{3}$ in the middle of the coal pillar was $1.7 \mathrm{~m}$ in width. Combining the three parts, the minimum width of the coal pillar was determined to be $5.8 \mathrm{~m}$. The width of the small coal pillar was set to $6.0 \mathrm{~m}$ in this study.

\subsection{Distribution of Advanced Abutment Pressure.} Excavation and maintenance of roadways under a stable internal stress field are crucial for preventing and controlling the large deformation of roadways and related disasters.
Numerical simulations were performed to study the characteristics of the distribution of advanced abutment pressure during mining of working face 130203 and the deformation and failure of the airway of working face 130205 during excavation and stoping. An FLAC3D numerical simulation model was established according to the physical and mechanical parameters of coal and the geological characteristics of Zaoquan Coal Mine, as shown in Figure 4. The working face and the roadway were arranged in the central area of the model, and the grid was densely divided in the part around the roadway. The numerical model comprised 285,600 grid units. The left and right boundaries of the model were constrained by horizontal displacement conditions, and the lower boundary was constrained by vertical displacement. The upper boundary was a free boundary with a uniform load. The size of the computational model was set as $311 \mathrm{~m} \times 300 \mathrm{~m} \times 227 \mathrm{~m}$.

During the simulation, excavation of working face 130203 was first conducted to observe the lateral abutment pressure distribution characteristics of the working face, and the results are presented in Figure 5. The lateral stress distribution of the working face was divided into low-stress $(0 \sim 5 \mathrm{~m})$, high-stress $(5 \sim 11 \mathrm{~m})$, peak-stress $(11 \sim 20 \mathrm{~m})$, and stress-relief zones $(20 \sim 50 \mathrm{~m})$. This indicates that the range of lateral impact due to the excavation of the working face was approximately $50 \mathrm{~m}$. The $6 \mathrm{~m}$ coal pillar was just outside the peak-stress zone, verifying the accuracy of the calculation results.

\subsection{Deformation and Failure Pattern of Coal Pillar during} Excavation. After the excavation of working face 130203 was completed and the movement of the overlying strata was stabilised, excavation of the airway of working face 130205 was conducted. The deformation and failure of the surrounding rocks of the roadway 150 and $180 \mathrm{~m}$ from the cutting hole during the excavation are shown in Figures 6 and 7 , respectively.

The results suggest that the deformation of the rock around the airway gradually increased. The deformation value was particularly large near the vault. The maximum deformation near the airway was $114.4 \mathrm{~mm}$ (180 $\mathrm{m}$ from the cutting hole). The vault extended upwards, and the deformation of strata converged quickly. The deformation of the surrounding rock was within $10 \mathrm{~mm}$, after extending $5 \mathrm{~m}$ into the rock. The maximum uplift at the bottom was approximately $45 \mathrm{~mm}$. The two sidewalls exhibited highly asymmetric deformation distributions owing to the heterogeneity of the cross section.

\subsection{Deformation and Failure Pattern of Coal Pillar during} Stoping. After the excavation of the airway of working face 130205 was complete, the excavation of working face 130205 was conducted. The deformation and failure of the coal pillar were observed, and the failure of the surrounding rocks of the roadway 150 and $180 \mathrm{~m}$ from the cutting hole is shown in Figure 8. During the advancement of the working face with a large mining height, the coal wall of the working face failed in a certain range along the advancement direction under the action of abutment pressure. The depth range of 0 to $2.0 \mathrm{~m}$ in 


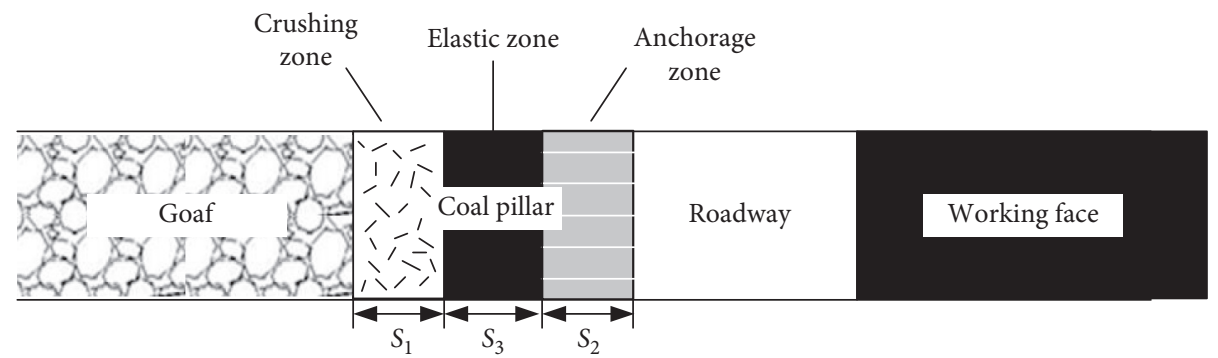

Figure 3: Schematic of roadway driving along the goaf and the small coal pillar.

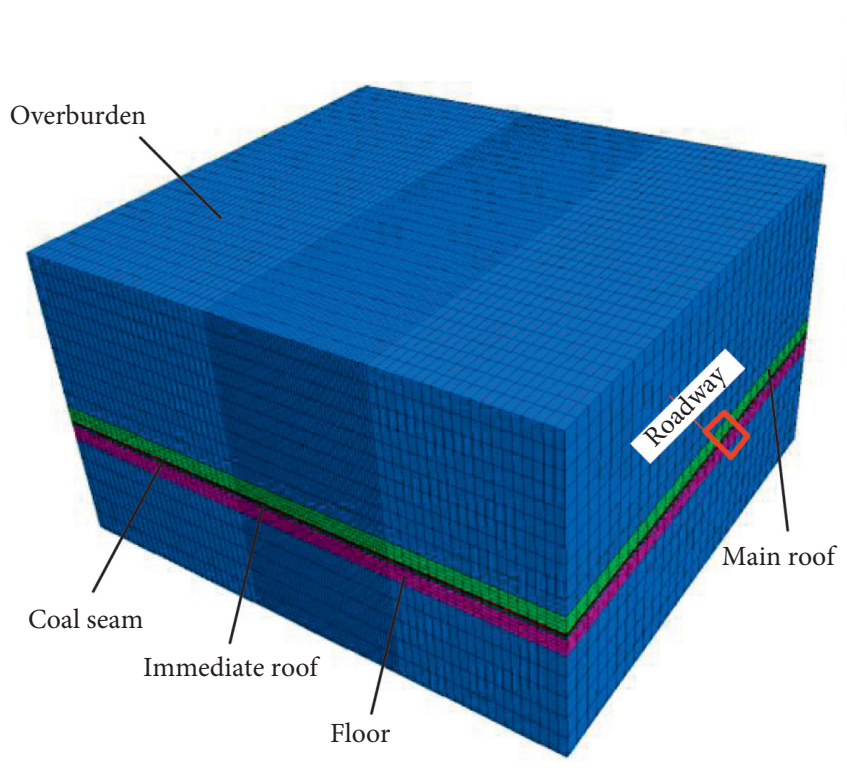

(a)

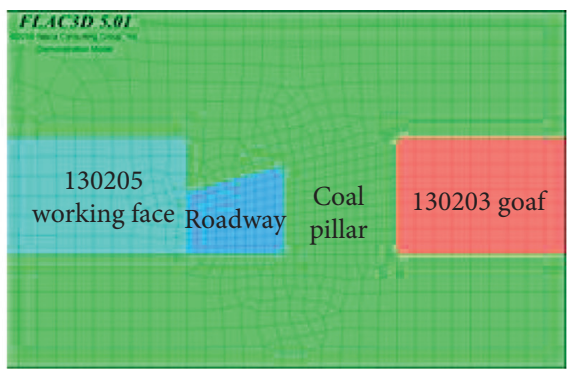

(b)

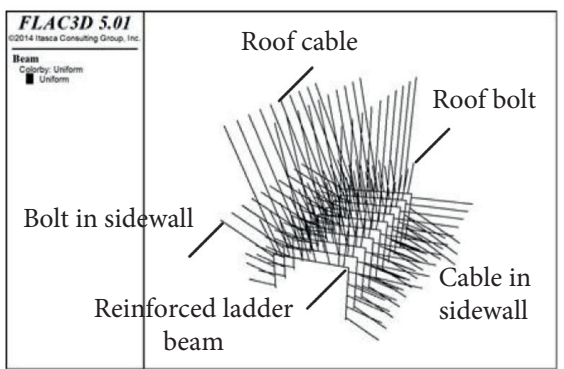

(c)

Figure 4: Grid diagram of the three-dimensional numerical model.

the coal wall on the side of mining face 130205 was the tensile and shear plastic zone, which was characterised by a typical failure in the form of outward bulging. Under the action of the abutment pressure, the reduction in the strength of the coal mass caused the coal wall at the working face to bulge outward. The depth range of 0 to $1.5 \mathrm{~m}$ in the coal wall on the side of mining face 130203 was the tensile and shear plastic zone. Under the action of the abutment pressure, the reduction of the strength of the coal mass led to the outward bulging of the coal wall at the working face. Within the range of 2.0 to $4.5 \mathrm{~m}$ in the centre of the small coal pillar, although part of the coal seam was in the plastic zone, the coal seam was mainly in the shear plastic zone, and the degree of rock fragmentation was not severe.

The comprehensive analysis indicated that there was approximately $1.5 \mathrm{~m}$ of noncrushing zone in the centre of the $6 \mathrm{~m}$ small coal pillar.

4.5. Application Results. The cross-point method [30] was used to monitor the degree of deformation of the surrounding rock of airway 130205 . Measuring pins were installed at the centres of the roof, floor, and two sidewalls. The degrees of deformation of these parts were measured once a day using a steel tape measure. The deformation of the roadway $150 \mathrm{~m}$ and $180 \mathrm{~m}$ from the cutting hole during the advancement of the working face is shown in Figure 9.

The deformation of the two sidewalls of the roadway was greater than those of the roof and floor during the advancement of the working face. The maximum sinkage of the roof was $55 \mathrm{~mm}$, the maximum heave of the floor was $55 \mathrm{~mm}$, the maximum upper-wall bulge was $30 \mathrm{~mm}$, and the maximum lower-wall bulge was $70 \mathrm{~mm}$. The bulging of the upper wall of the airway was the smallest among all the changes, indicating that a $6 \mathrm{~m}$ coal pillar can maintain the stability of the roadway. Within $50 \mathrm{~m}$ from the working face, the deformation of the surrounding rock of the roadway became increasingly apparent. The deformation accelerated significantly within $35 \mathrm{~m}$, and the deformation rate was maximised at approximately $20 \mathrm{~m}$. Thus, the influence range during the process of stoping of the working face was roughly within $50 \mathrm{~m}$. The deformation of the roof increased significantly within $20 \mathrm{~m}$ ahead of the working face, and a sharp increase occurred at approximately $15 \mathrm{~m}$. This indicates that the coal seam mining generally affected a range $50 \mathrm{~m}$ ahead of the coal wall and that the impact of the mining intensified within the range of $15 \mathrm{~m}$. 


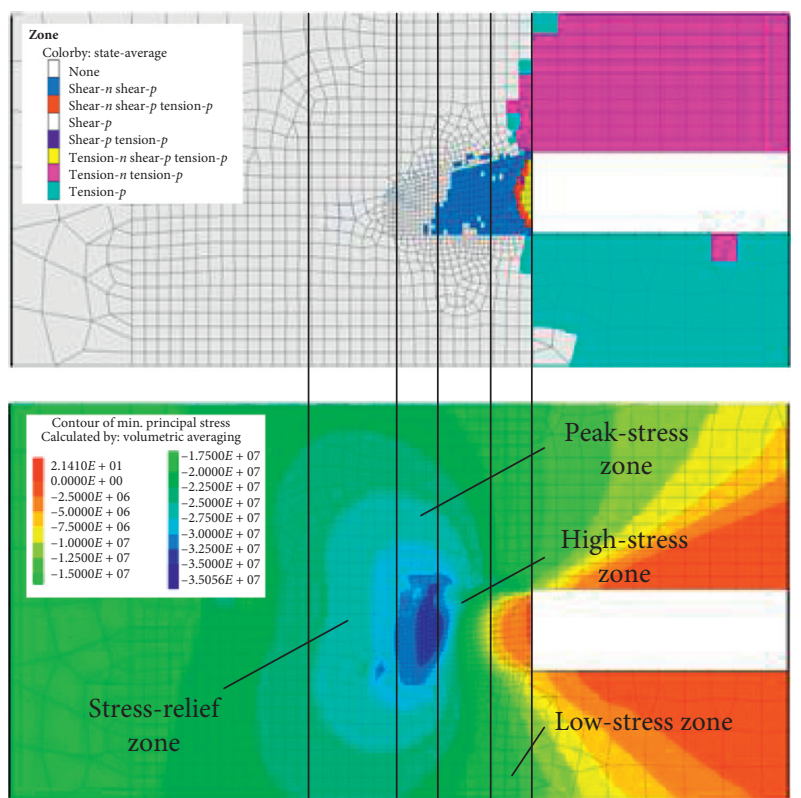

(a)

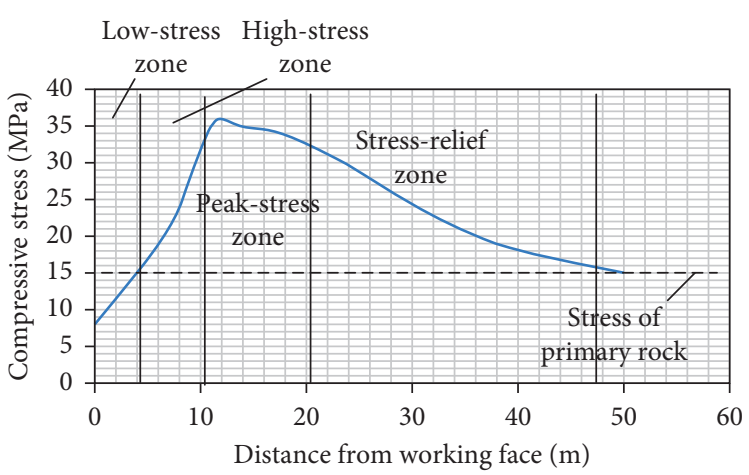

(b)

FIGURE 5: Distribution of the advanced abutment pressure at the working face during stoping. (a) Vertical view and (b) stress distribution curve.

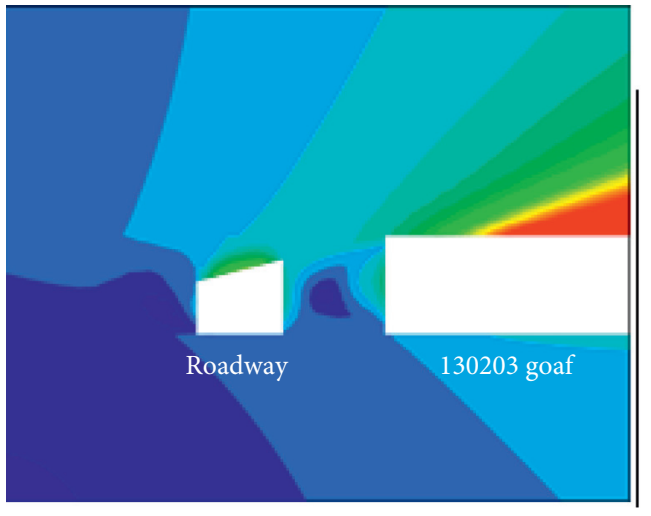

(a)

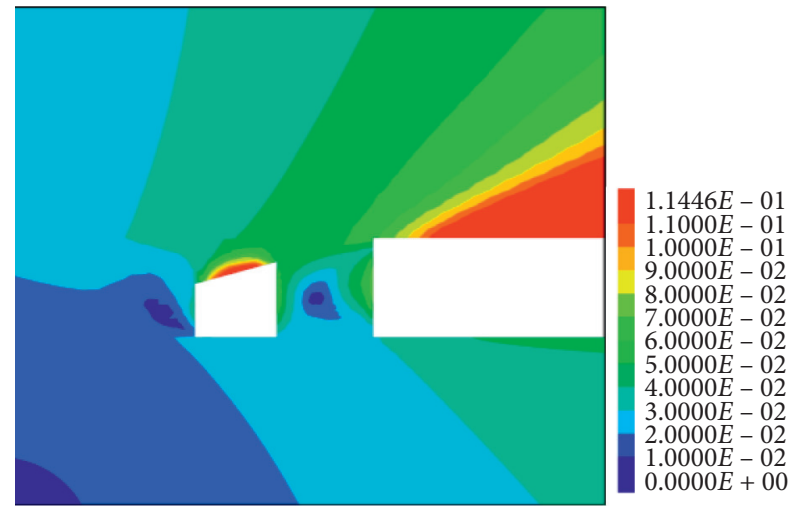

(b)

Figure 6: Nephograms indicating the rock deformation during airway excavation. (a) $150 \mathrm{~m}$ from the cutting hole and (b) $180 \mathrm{~m}$ from the cutting hole.

The YS(B) explosion-proof electronic borescope for mines (as shown in Figure 10) was used to detect the failure in the coal pillar $50 \mathrm{~m}$ ahead of the working face, and the results are shown in Figure 11. At the front end of the borehole (i.e., near working face 130203), fractures developed in the borehole, and the coal mass was crushed. At the middle of the borehole, the borehole wall was relatively smooth, with high integrity. At the back end of the borehole (i.e., near working face 130205), the borehole wall appeared to be bright black under the illumination of the probe, indicating that the coal mass here was also in the plastic state. The detection results indicated that both sides of the coal pillar were in a state of plastic failure, while there was still an intact elastic core zone in the middle, which indicates that the design of the coal pillar is reasonable. This was supported by the overall results for the deformation control of the roadway. The effects on the roadway 50 and $100 \mathrm{~m}$ ahead of the working face are presented in Figure 12. As shown, the deformation of the roadway along the goaf with a $6 \mathrm{~m}$ small coal pillar was not apparent within the influence range of advanced abutment pressure, which can ensure normal stoping of the working face.

4.6. Discussion. The method for determining the width of gob-side coal pillar proposed in this paper is applicable to all coal mines in theory. However, when the roadway roof is hard, it needs to be supplemented by roof cutting and other measures to prevent excessive stress on the coal pillar. The broken position of soft roof is close to the coal pillar, so it is not necessary to take other measures, so the method in this paper can be directly used for design. 


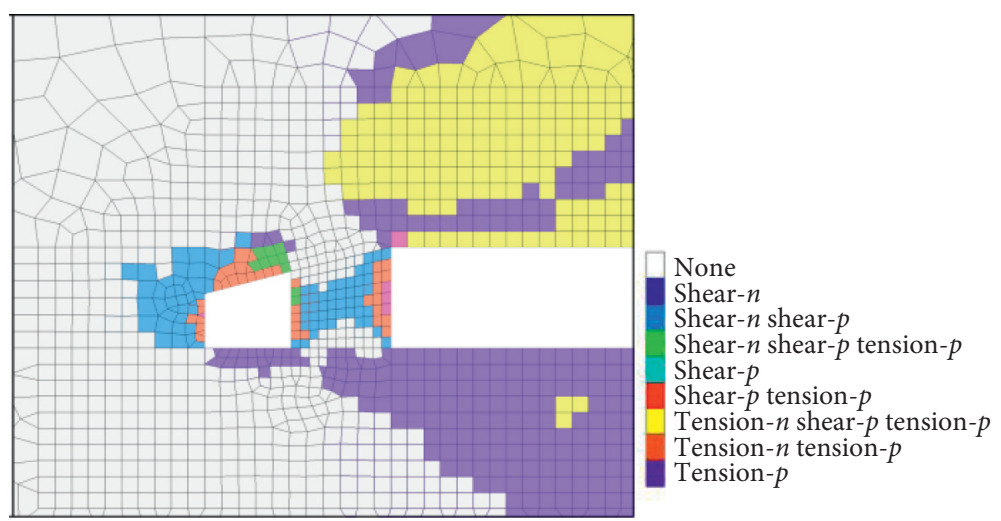

(a)

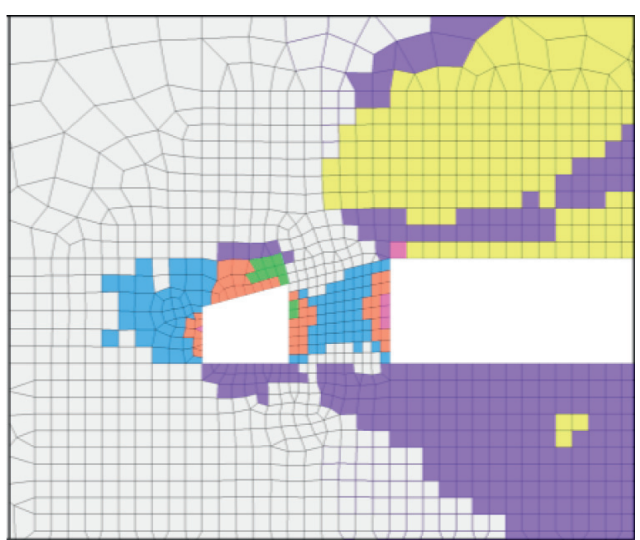

(b)

FiguRe 7: Distribution of the plastic zone of the rock during the airway excavation. (a) $150 \mathrm{~m}$ from the cutting hole and (b) $180 \mathrm{~m}$ from the cutting hole.

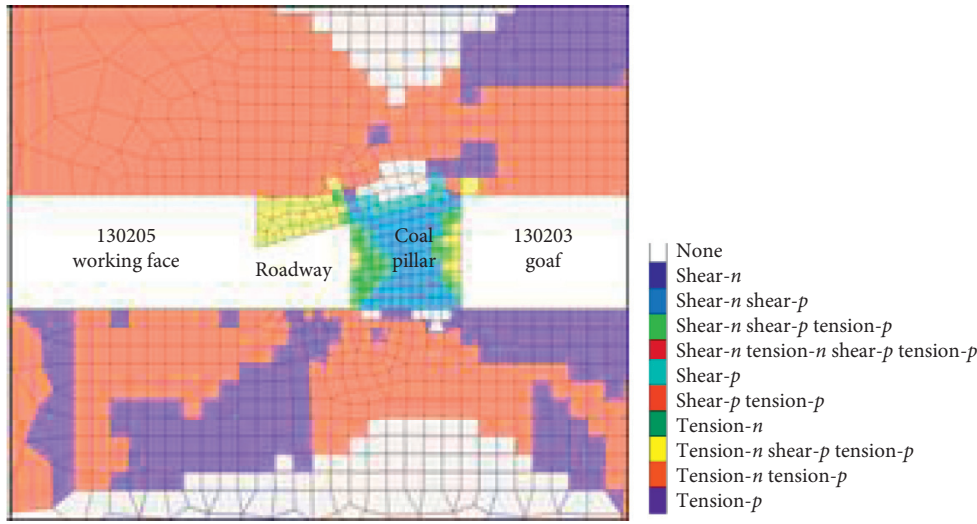

(a)

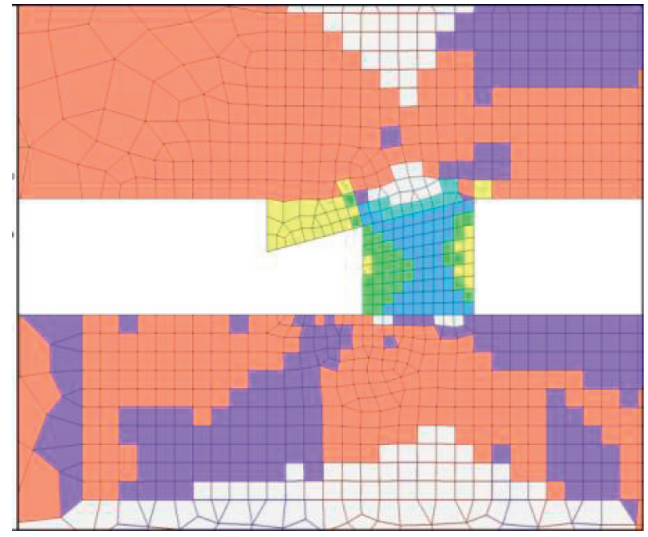

(b)

FIGURE 8: Distribution of the plastic zone of the rock body at the working face during stoping. (a) $150 \mathrm{~m}$ from the cutting hole and (b) $180 \mathrm{~m}$ from the cutting hole.

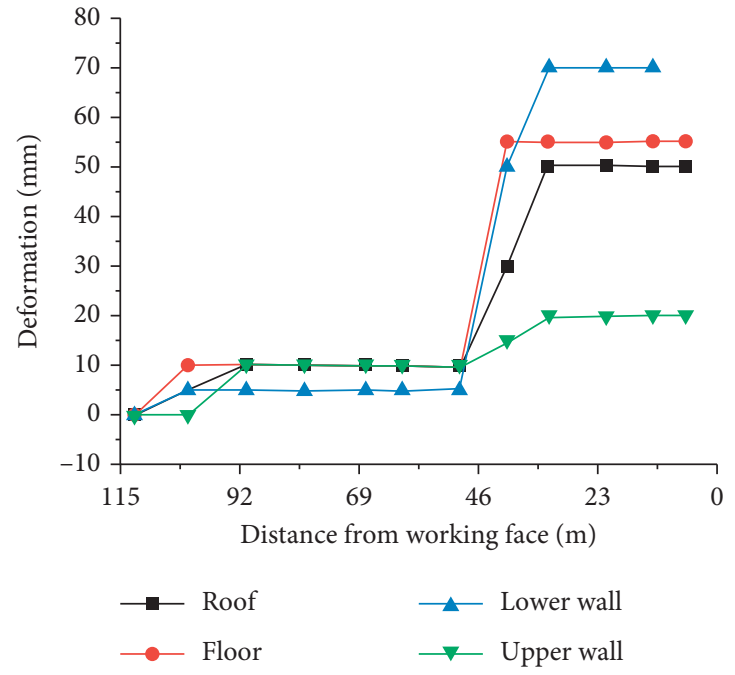

(a)

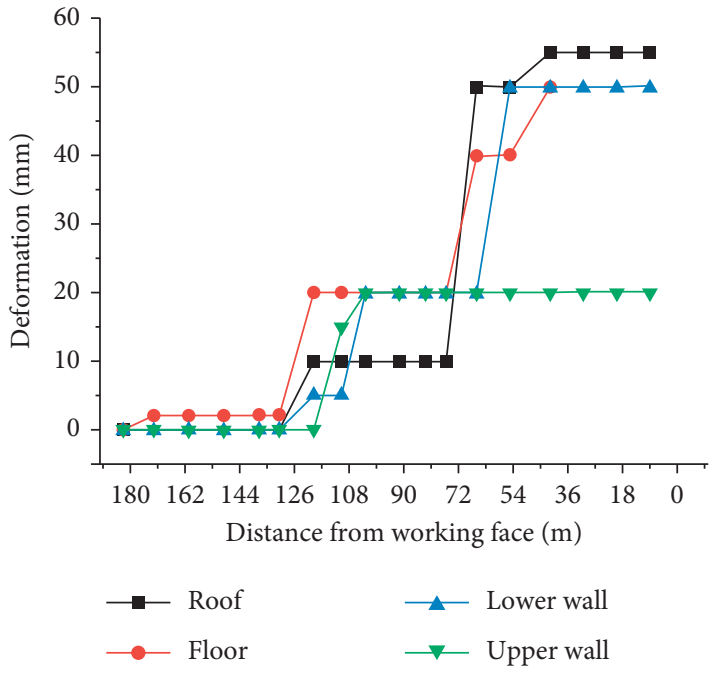

(b)

FIGURE 9: Deformation of the surrounding rocks of the roadway at different distances from the cutting hole. (a) $150 \mathrm{~m}$ from the cutting hole and (b) $180 \mathrm{~m}$ from the cutting hole. 


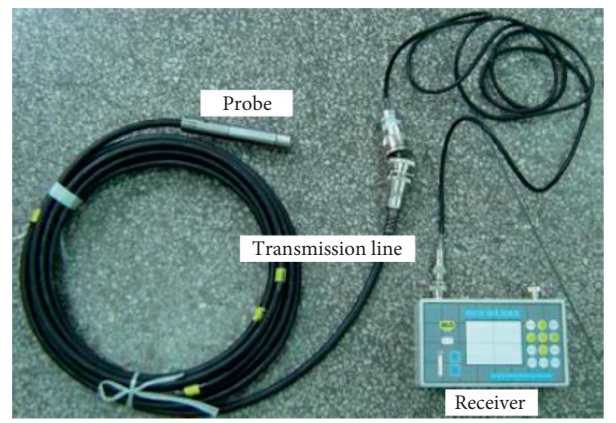

Figure 10: Detection equipment for internal fracture of the coal mass.

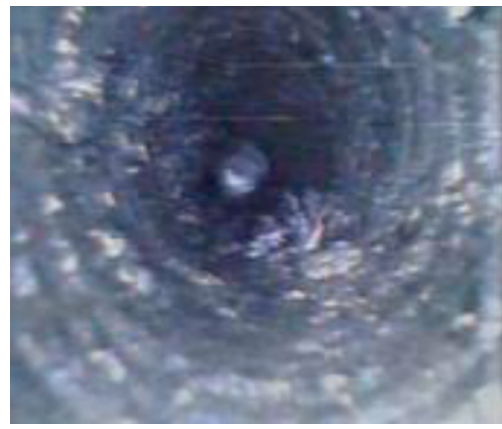

(a)

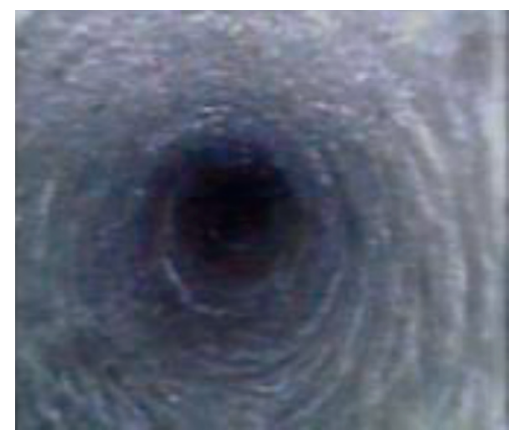

(b)

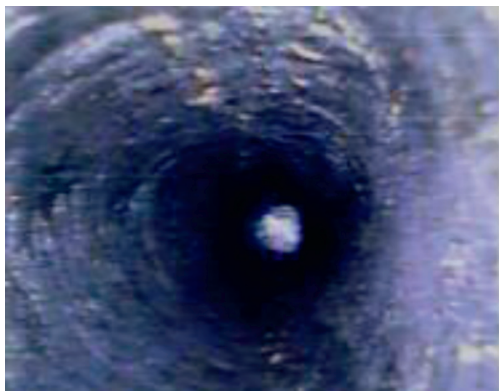

(c)

Figure 11: Internal fracture development in the coal mass. (a) Front-end crushing zone, (b) middle intact zone, and (c) back-end anchorage zone.

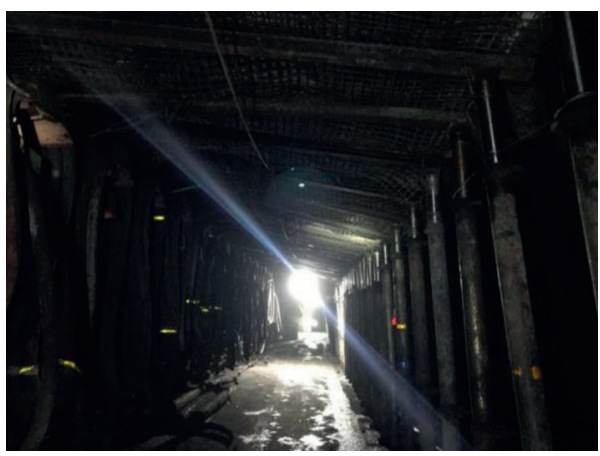

(a)

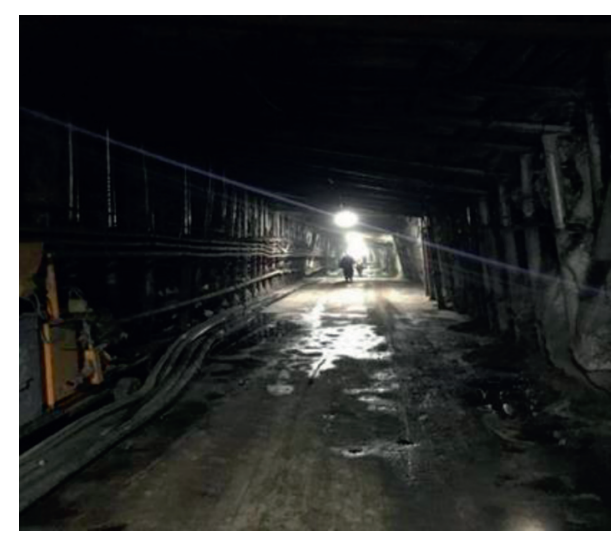

(b)

Figure 12: Effects on the roadway with 50 and $100 \mathrm{~m}$ of working face advancement. (a) $50 \mathrm{~m}$ of advancement and (b) $100 \mathrm{~m}$ of advancement.

\section{Conclusions}

In the design of a coal pillar in roadway driving along a goaf, not only the width of the coal pillar but also its location must be considered. In this study, a method for determining the location and width of a small coal pillar was developed on the distribution of the internal and external stress fields at the working face. The method was applied to working face 130205 of Zaoquan Coal Mine.

(1) According to the calculation of the width of the limit equilibrium zone generated in the coal pillar at working face 130205 and the mechanical calculation of the joint loading in the limit equilibrium zone and the elastic core zone of the coal pillar, a reasonable width of the coal pillar of the section was found to be $6 \mathrm{~m}$. This result is consistent with the simulation results for the distribution of the lateral abutment pressure after the mining of working face 130203.

(2) During the excavation of the roadway and stoping of the working face, the deformation of the roadway increased with a reduction in the distance from the working face. Owing to the asymmetry of the 
roadway, plastic failure of the solid coal side of the roadway was apparent. Although plastic failure also occurred in the coal pillar, its bearing capacity was still relatively high. There was approximately $1.5 \mathrm{~m}$ of intact zone in the middle of the coal pillar even during the stoping of the working face.

(3) The influence range during the stoping of the working face was roughly $50 \mathrm{~m}$, and the deformation of the roof increased significantly within $20 \mathrm{~m}$ ahead of the working face. The deformation of the two sidewalls of the roadway exceeded those of the roof and floor, and the bulging of the upper wall was the smallest among all the changes, indicating that a $6 \mathrm{~m}$ small coal pillar can effectively maintain the stability of the roadway. This is consistent with the conclusion from the exploration of the coal pillar through the borehole onsite that there is an intact zone in the centre of the coal pillar.

(4) The proposed design method for small coal pillars in deep roadway driving along goafs is scientific and reliable. It provides a scientific basis for the determination of the reasonable width of narrow coal pillars, which can improve the maintenance status of deep roadways and increase the coal recovery rate.

\section{Data Availability}

The data used to support the findings of this study are available from the corresponding author upon request.

\section{Conflicts of Interest}

The author declares that he has no conflicts of interest.

\section{Acknowledgments}

This work was supported by the Key R\&D Program of Shandong Province (no. 2019GSF111020). The support was greatly appreciated.

\section{References}

[1] J. Martin and W. Holger, "Progress in the research and application of coal mining with stowing," International Journal of Mining Science and Technology, vol. 23, pp. 7-12, 2013.

[2] M. L. Hu, W. L. Zhao, Z. Lu, J. X. Ren, and Y. P. Miao, "Research on the reasonable width of the waterproof coal pillar during the mining of a shallow coal seam located close to a reservoir," Advances in Civil Engineering, vol. 2019, Article ID 3532784, 14 pages, 2019.

[3] Q. Wang, Y. P. Fan, G. Li, W. X. Guo, D. H. Yan, and L. P. Zhang, "Determination of coal pillar width between roadways of fully mechanised caving face with double roadways layout in a thick coal seam," Rock and Soil Mechanics, vol. 38, pp. 3009-3016, 2017.

[4] K. Wang, T. Zhao, K. Yetilmezsoy, and X. Q. Zhang, "Cuttingcaving ratio optimization of fully mechanized caving mining with large mining height of extremely thick coal seam," Advances in Civil Engineering, vol. 2019, Article ID 7246841, 11 pages, 2019.
[5] W. Liu, Z. Guo, J. Hou, and D. Chen, "Research and application of support technology for re-mining roadway in goaf under regenerated roof in thick coal seam," Geotechnical \& Geological Engineering, vol. 37, no. 5, pp. 4327-4335, 2019.

[6] Y. Xue, P. G. Ranjith, F. Dang et al., "Analysis of deformation, permeability and energy evolution characteristics of coal mass around borehole after excavation," Natural Resources Research, vol. 29, no. 5, pp. 3159-3177, 2020.

[7] X. S. Liu, D. Y. Fan, Y. L. Tan et al., "Failure evolution and instability mechanism of surrounding rock for close-distance chambers with super-large section in deep coal mines," International Journal of Geomechanics, vol. 21, no. 5, Article ID 04021049, 2021.

[8] Y. Xue, T. Teng, F. Dang, Z. Ma, S. Wang, and H. Xue, "Productivity analysis of fractured wells in reservoir of hydrogen and carbon based on dual-porosity medium model," International Journal of Hydrogen Energy, vol. 45, no. 39, pp. 20240-20249, 2020.

[9] J. Zhang, F. Jiang, S. Zhu, and L. Zhang, "Width design for gobs and isolated coal pillars based on overall burst-instability prevention in coal mines," Journal of Rock Mechanics and Geotechnical Engineering, vol. 8, no. 4, pp. 551-558, 2016.

[10] Z. Zhu, H. Zhang, J. Nemcik, T. Lan, J. Han, and Y. Chen, "Overburden movement characteristics of top-coal caving mining in multi-seam areas," The Quarterly Journal of Engineering Geology and Hydrogeology, vol. 51, no. 2, pp. 276286, 2018.

[11] Y. L. Tan, F. H. Yu, J. G. Ning, and T. B. Zhao, "Design and construction of entry retaining wall along a gob side under hard roof stratum," International Journal of Rock Mechanics and Mining Sciences, vol. 77, pp. 115-121, 2015.

[12] E. Ghasemi and K. Shahriar, "A new coal pillars design method in order to enhance safety of the retreat mining in room and pillar mines," Safety Science, vol. 50, no. 3, pp. 579-585, 2012.

[13] P. R. Sheorey, M. N. Das, D. Barat, R. K. Prasad, and B. Singh, "Coal pillar strength estimation from failed and stable cases," International Journal of Rock Mechanics and Mining Science \& Geomechanics Abstracts, vol. 24, no. 6, pp. 347-355, 1987.

[14] M. Najafi, S. E. Jalali, A. R. Y. Bafghi, and F. Sereshki, "Prediction of the confidence interval for stability analysis of chain pillars in coal mines," Safety Science, vol. 49, no. 5, pp. 651-657, 2011.

[15] W. He, F. He, and Y. Zhao, "Field and simulation study of the rational coal pillar width in extra-thick coal seams," Energy Science \& Engineering, vol. 8, no. 3, pp. 627-646, 2020.

[16] N. Fan, J. Wang, B. Zhang, D. Liu, and R. Wang, "Reasonable width of segment pillar of fully-mechanized caving face in inclined extra-thick coal seam," Geotechnical \& Geological Engineering, vol. 38, no. 4, pp. 4189-4200, 2020.

[17] W. J. Gale, "Experience of field measurement and computer simulation methods for pillar design," in Proceedings of the Second International Workshop on Coal Pillar Mechanics and Design, US National Institute for Occupational Safety and Health, Pittsburgh, PA, USA, June 1999.

[18] A. Jaiswal and B. K. Shrivastva, "Numerical simulation of coal pillar strength," International Journal of Rock Mechanics and Mining Sciences, vol. 46, no. 4, pp. 779-788, 2009.

[19] G. S. Esterhuizen, C. Mark, and M. M. Murphy, "Numerical model calibration for simulating pillars, gob and overburden response in coal mines," in Proceedings of the 29th International Conference on Ground Control in Mining, West Virginia University, Morgantown, WV, USA, July 2010. 
[20] W.-d. Wu, J.-b. Bai, X.-y. Wang, S. Yan, and S.-x. Wu, "Numerical study of failure mechanisms and control techniques for a gob-side yield pillar in the Sijiazhuang coal mine, China," Rock Mechanics and Rock Engineering, vol. 52, no. 4, pp. 1231-1245, 2019.

[21] J. B. Bai, C. J. Hou, and H. F. Huang, "Numerical simulation study on stability of narrow coal pillar of roadway driving along goaf," Chinese Journal of Rock Mechanics and Engineering, vol. 20, pp. 3475-3479, 2004.

[22] K. Chen, J. B. Bai, and Q. Zhu, "Failure law of small coal pillar and determination of reasonable width in gob side entry driving," Safety in Coal Mines, vol. 40, no. 8, pp. 100-102, 2009.

[23] X. G. Zheng, Z. G. Yao, and N. Zhang, "Study on stress distribution of small coal pillar in gob side entry driving in the whole process of mining," Journal of Mining and Safety Engineering, vol. 29, no. 4, pp. 459-465, 2012.

[24] X. S. Liu, D. Y. Fan, Y. L. Tan et al., "New detecting method on the connecting fractured zone above the coal face and a case study," Rock Mechanics and Rock Engineering, 2021.

[25] G. Zhang, L. Chen, Z. Wen et al., "Squeezing failure behavior of roof-coal masses in a gob-side entry driven under unstable overlying strata," Energy Science \& Engineering, vol. 8, no. 7, pp. 2443-2456, 2020.

[26] Z. Zhao, W. Sun, S. Chen, D. Yin, H. Liu, and B. Chen, "Determination of critical criterion of tensile-shear failure in Brazilian disc based on theoretical analysis and meso-macro numerical simulation," Computers and Geotechnics, vol. 134, Article ID 104096, 2021.

[27] B. Wang, F. Dang, S. Gu, R. Huang, Y. Miao, and W. Chao, "Method for determining the width of protective coal pillar in the pre-driven longwall recovery room considering main roof failure form," International Journal of Rock Mechanics and Mining Sciences, vol. 130, Article ID 104340, 2020.

[28] S. H. Prassetyo, M. A. Irnawan, G. M. Simangunsong, R. K. Wattimena, I. Arif, and M. A. Rai, "New coal pillar strength formulae considering the effect of interface friction," International Journal of Rock Mechanics and Mining Sciences, vol. 123, Article ID 104102, 2019.

[29] G. S. Jia and L. J. Kang, "Study on the chain pillar stability of the developing entry in longwall top-coal mining," Journal of China Coal Society, vol. 27, pp. 6-10, 2002.

[30] J. Ning, J. Wang, Y. Tan, and Q. Xu, "Mechanical mechanism of overlying strata breaking and development of fractured zone during close-distance coal seam group mining," International Journal of Mining Science and Technology, vol. 30, no. 2, pp. 207-215, 2020. 